\title{
Consideration of Higher Vocational Colleges English Teaching Against the Background of "the Belt and Road" Initiative
}

\author{
Yun Zhou \\ Yunnan College of Business Management: Kunming 650304 China
}

Keywords: The Belt and Road initiative; higher vocational colleges; English professionals.

\begin{abstract}
The Belt and Road Initiative is the top national strategy under new economy, its implementation contributing to build and improve regional economic cooperation platforms and creating the dual multilateral mechanism among China and the countries along the Belt and Road. Meanwhile, the Belt and Road initiative, as national top strategy, more and more English professionals have been necessary for ensuring its successful implementation and construction while developing and improving continuously. In this case, the training mode of English professionals has transformed a lot in higher vocational colleges and universities. Based on relevant research about the Belt and Road initiative construction, this paper attaches great importance to English professionals training, probes into corresponding countermeasures for higher vocational college English teaching and gains a good impetus for our Belt and Road construction and planning.
\end{abstract}

\section{Introduction}

In 2013, general secretary Xi Jinpin launched the strategic conception "the Belt and Road initiative", short for "the silk road economic belt and the 21st century Maritime silk road", providing new growth points for cooperation of Asia and pan-Asian economies in the new economic situation. A new development pattern has been formed for the Belt and Road strategy. It indicates that our country starts to actively seek for new approaches and international markets good for national resources for foreign development, achieving the transformation of industrial and economic patterns better. Meanwhile, the three pillars of financial organizations have provided strong support for the Belt and Road initiative, which are the Silk Road Fund, Asian Infrastructure Investment Bank and the original Brics Bank. However, considering the development of the Belt and Road initiative, taking China's place on the worldwide market and English professionals demanded for political stage, it is necessary for our English learning education to achieve the development from professional orientation to employment orientation, and this leads to bring different English professionals training modes.

\section{Background and Connotation of the Belt and Road Initiative}

\subsection{Background of the Belt and Road Initiative}

The launching of the Belt and Road initiative is based on its profound historical background. Our economic development and reform has encountered resistance. The open strategy has been confronted with transformation and updating. Our economic development has been with slowing pace and less supportive. The objective law of national economic development has determined the emerging of a new phase, which is the superposition of period for adjusting growing speed, structural transformation and digesting the policy in the early stage. Since 21 st century, for the rapid development of national economy and structural redundancy, sudden revolution of economic situation has brought new challenges for long-term economic development pattern. Resolving the deep-seated contradictions of economic development for several years has been demanded to settle urgently in the new economy. Moreover, with the RMB joining in the SDR, the integration of international economy being intensified, the situation of regional economic construction turning more complex, and global economy growing, China's economy has been confronted with new requirements. So our country is in the state of economic development under internal and external pressure. Given that our economic development needs to build interconnected economic and trade relations with neighboring economies 
to enlarge regional impact and deepen the influence in the international economic field, the Belt and Road initiative has emerged at the moment. With founding the Belt and Road initiative, China has won a more prominent position in the far-east economic development and global economic trade.

\subsection{Connotation of the Belt and Road Initiative}

The Belt and Road initiative has been interpreted west development strategy of China to a certain extent. The international and domestic aspects (Li Jianming, 2013) are the important platforms of this strategy. General secretary Xi Jinping first put forward the conception to build "the silk road economic belt" and "the Maritime silk road", when he visited the four central Asian states and Indonesia in September and October 2013. Later on, as a comprehensive and strategic conception, the specific frameworks and concepts of the Belt and Road initiative has been further deepened. In terms of strategic connotation, it accelerates regional cooperation and integration, creates strategic cooperation among China and other Asian countries to form a community of common destiny, and continuously deepens mutual assistance with western developed countries. In the aspect of cultural connotation, it flourishes the ancient silk road, extends historical spirit, encourages the cultural development construction in the new era and provides some ideas and reference. And for economic connotation, it promotes the economic interaction and trade exchanges among China and the economies along the line, flourishes regional economies and deepens the status of our export trade in the international market.

\section{Opportunities and Challenges Faced by Higher Vocational Colleges in the Belt and Road Initiative}

\subsection{Opportunities Brought with the Open and Inclusive International Communication Mode}

With carrying out the Belt and Road initiative, China has developed continuously to communicate and interact with the world. In the specific case of higher vocational English education, it has been reflected in the increasing number of international students and a good interaction between science communication and cross-domain constructions. Also, the advanced foreign education ideas and international student education environment have given great support to interact and develop among our higher colleges and universities. The higher vocational English teaching has faced with new impetus. Our international influence as an ancient nation has been especially prominent on account of 5000 years historical civilization of our country. Our culture, historical sites and intangible cultural heritage stands out with the glorious history. This makes our country more confident in sino-foreign cultural exchanges, better fitting for higher vocational colleges to carry out communication and learning of English teaching and promoting Chinese culture by using English education. In recent years, the higher educational resources have increasingly expanded, creating a good condition for developing our special English education. China should seize this chance to strive for innovating education forms and ideas, serving the development of higher vocational English education. It is an important opportunity for our higher vocational English education.

\subsection{New Challenges Faced by Higher Vocational College Internal Management for Lacking Innovation}

The higher vocational colleges have the same management objectives and requirements with other administrative institutions, demanding to take full use of their own resources, optimize several management contents including financial management, human resources management, cost management and instructional resources management. Currently, the higher vocational colleges still exist some difficulties in self-management, such as loose institution and poor quality of financial staff in the financial management. These pervasive problems existing in the higher vocational college management have caused great hardship for carrying out the relevant requirements of the Belt and Road initiative. Firstly, the internal higher vocational colleges have no successfully feasible experience about the combination of English and the Belt and Road initiative. The relative education researchers have no accurate approaches for how to develop higher vocational English education in the new era. The teachers still instruct students according to previous teaching methods in the practical teaching, and a lot problems can come out in teaching management. Secondly, the English education of domestic higher vocational colleges has lacked systematization and systematic arrangement in the 
long term, not attaching great importance to the difference of teaching contents and education system of higher vocational English and English education in the general universities.

Then, there is no coincidence for the development of the Belt and Road and higher vocational English education in the new situation. While the Belt and Road initiative continuously developing, the colleges need to grasp current policy timely, specifically adjust teaching direction and add new teaching philosophy, and reform the corresponding teaching methods and materials. However, given that the management systems of ordinary higher vocational colleges have lacked innovation and executive abilities, it is hard to accurately carry out the requirements of English teaching under the Belt and Road initiative demanded by the higher-level leadership of schools.

\section{Countermeasures of Higher Vocational English Teaching Under the Belt and Road}

\subsection{Change Education Methods, Achieve Personal Development of Students}

Emphasizing on personal development of students has similarities with the development of higher vocational English education. Developing students-orientation education of higher vocational English can also embody in strengthening the cultivation of students' English literacy under the Belt and Road. The Belt and Road initiative has emphasized on intensifying the basic abilities of professionals, developing students with consciousness of learning and innovation targetedly. Therefore, in the actual teaching section, it is necessary for students to grasp the grammar and English dialogue scene, especially the teaching and learning of applied English. The key word of the Belt and Road is to integrate into international economic ecosystem actively. The development of applied English should not be taken slightly. The teachers should amplify to propagandize and explain the Belt and Road while classroom teaching, increasingly achieve to expand the scope of knowledge in classroom teaching, and push forward the reform of teaching resources under the Belt and Road initiative, as well as emphasize the positive impact of traditional classroom teaching to students' knowledge, making students fully realize the requirements and approaches to achieve the Belt and Road initiative on training the English professionals.

\subsection{Emphasize to Innovate Teaching System, Optimize Course Management 4.2.1 Innovate Teaching System of Education.}

It has been mentioned above that there still exist some problems about how to bind the Belt and Road initiative with higher vocational English talents training mode in colleges and universities. So it is primary to innovate education methods for achieving the goal. Internationally, English talents have been demanded to be internationalized and diversified. The best training mode is a combination of E, double major and minority language. For employment orientation, as well as for the Belt and Road, the cultivation of English major graduates must be in accordance with social development.

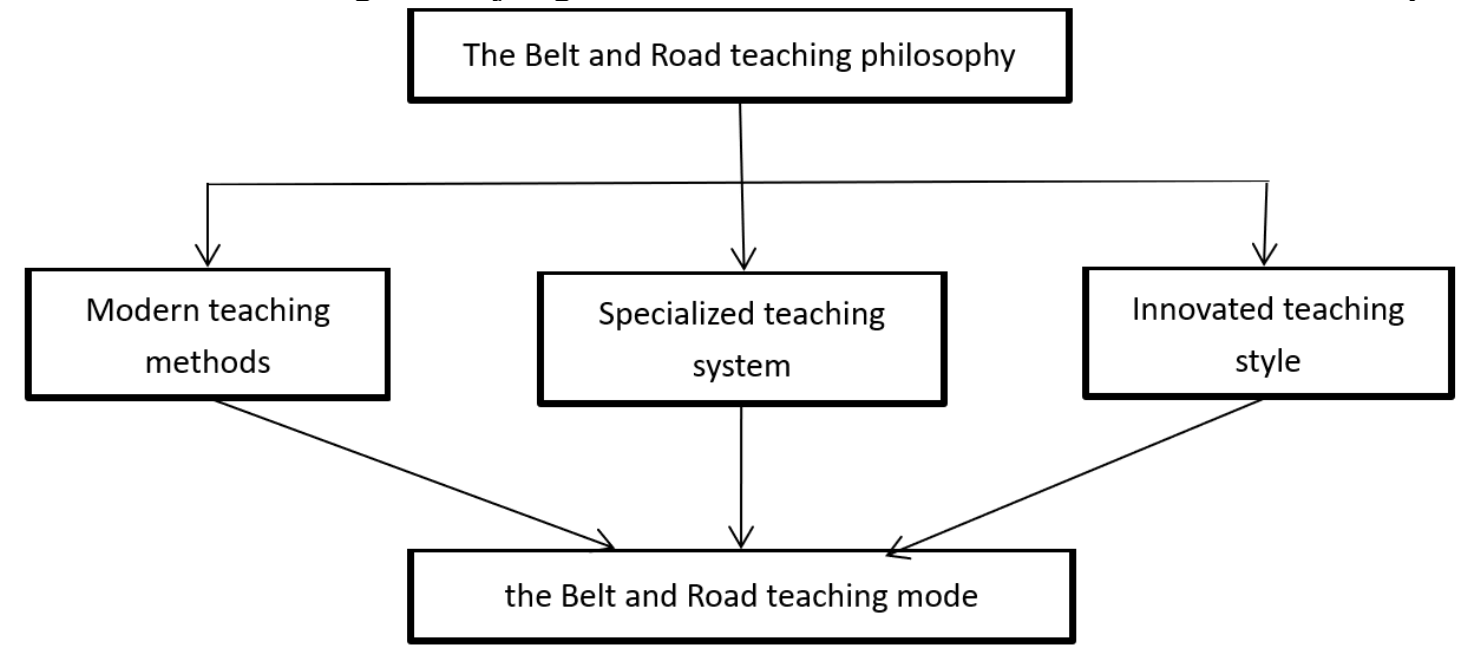

Fig. 1. Chart of the Belt and Road teaching system

\subsubsection{Arrange Courses Scientifically and Rationally.}

Designing curriculum should be based on the combination of English, specialty and second language. The English one means the English skill-based courses and English basic courses, the 
specialty means the professional ability courses closely related to market demands under the Belt and Road, and the second language means minority language. Certainly, the types of curriculum should be set according to the current departments of schools and arrange rationally the proportion of the three parts. Moreover, by combining organically with the specialized courses theory, the internship training is set for shaping the students' practical abilities.

\subsubsection{Promote Teachers' Ability, Improve Professional Teaching Ability.}

The higher vocational English education has new development point under the Belt and Road. As the main force of English teaching, the teachers must realize their leading role enough, strengthen the learning of English professional knowledge and grasp deeply the new strategy and methods of higher vocational English education under the Belt and Road. And they also should bring up learning methods better fit for their practical situations of higher vocational English majors, emphasize the teaching in aspects of abilities and interests, promoting a comprehensive progress of quality and knowledge. The teachers should learn to take advantage of more diversified teaching ways to instruct students to have sufficient cognition and interests of modern English learning, then to promote the comprehensive development of higher vocational English education.

\subsection{Create Different Teaching Methods, Infiltrate International Demands}

Different teaching methods have different impact on students' learning. Currently, the higher vocational English teaching mostly adopt traditional teaching method, which is lectured by teachers, heard by students. This kind of way not only do not well applied the prevalent education philosophy, but also not benefit for arousing students' enthusiasm, transform passive learning to active exploring. For example, the situation dialogue is single in the current higher vocational English oral teaching. The students lack deep understanding of pragmatic scenarios. Therefore, it is reflected one learning atmosphere, just learning English for learning English. The students even completely forget the teaching contents outside the classroom. The actual English learning time and efficiency is quite low. However, with the continuous development of the Belt and Road initiative, the students' English ability and interests for inquiring English knowledge all have new requirements. The higher vocational English professionals need to join in regional construction actively in the future to play a leading role. English is an important tool for external exchanges and publicizing local characteristics. Different education methods demand to be created in the practical teaching, such as the task-driven approach, implementing practical writing in groups. In the section of writing, the students need to carry out the task, and analyze the details of articles well. By setting up the writing learning groups, the students can learn to balance individual learning and collective learning. Discussing task in the group and making writing issue clear contribute to facilitate writing learning. Therefore, it is necessary to strengthen the construction of English writing learning groups. That has important impact on the learning and interaction of English pragmatic courses. Firstly, it leads to a better internal learning atmosphere. The English education in the past mostly proceeded with big-class having several students. The actual teaching effect is not so good. Most of students have no better cognition about how to improve their writing level by combining theory with concrete writing task. The teachers also cannot make certain about the thought of different students. The distribution of teaching information still exists defects. Instead, the teaching group can limit the number of members, adopt the way of class committee leading while students following, and make mutual evaluation after finishing writing, and choose out some excellent articles to read before the whole class, thus to promote the interaction between students and teachers.

\section{Conclusion}

From the above, the paper has expounded some existing problems about cultivating English professionals under the Belt and Road, and further analyze it combining opportunities and challenges faced by English professionals. Finally, it puts forward the measures about strengthening the cultivation of employment-oriented English talents to provide reference for those related researchers, making our English professionals be in line with the Belt and Road initiative. 


\section{References}

[1]. Wang Tingting. First exploration of developing employment-oriented English professionals under the Belt and Road initiative[J]. Chinese Journal (foreign education teaching), 2016, (06): $105-108+124$.

[2]. Duan Xiaocong. Study of developing business English talents of higher vocational colleges under the Belt and Road initiative--taking vocational colleges in Guang dong province as an example[J]. Western quality education, 2015, 1 (07): 53+55.

[3]. Xie Ting. Cultivation of business English versatile talents under the Belt and Road initiative[J/OL]. Technology vision, 2017, (23): 196-197.

[4]. Zhang Guojian. Study of language skills of cross-border e-commerce English talents under the Belt and Road initiative--taking Xi an region as an example[J]. Economic research guide, 2017, (09): 133-135.

[5]. Liu Xiaofei. Cultivation of employment-oriented English professionals under the Belt and Road initiative[J]. Ability and wisdom, 2016, (28): 185. 